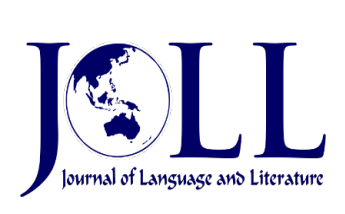
Jourmal of Language and Literature

Vol. 21 No. 1, April 2021, pp. $92-104$

DOI: 10.24071/joll.v21i1.2934

Available at https://e-journal.usd.ac.id/index.php/JOLL/index

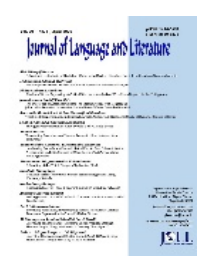

This work is licensed under a Creative Commons Attribution-ShareAlike 4.0 International License.

\title{
Towards a Textual Deconstruction of Adebowale's Lonely Days
}

\author{
Wolé Olúgúnlè \\ woleshadrach@gmail.com \\ Department of European Studies, University of Ibadan, NIGERIA
}

\begin{abstract}
No literary creation exists hermetically; it is not self-sufficient and independent. It does not emanate from a vacuum. Every literary creation is textually incorporated in relation; whether compulsorily, optionally or accidentally, to other pre-existing texts. This implies that the realization of a literary text by a writer results from the fact that such literary creator has studied several other pre-existing texts; thus it is presumptuous of a writer to claim the competence of producing a literary text without dialoging with existing ideas and ideologies, mours, legends and myths as well as pre-existing communication codes. But then, the objective of this study is to unearth and demonstrate how Adebowale, in his Lonely Days (2006), has related in either a compulsory, optional or accidental manner with existing ideas and ideologies, mours, legends and myths and pre-existing communication codes. With Kristevan methodology of intertextuality and critical textual analysis, the study succinctly deconstructs how the textual incorporation of the hypertext relates with the existing hypo-texts through the markers of intertextuality. The study finds out that, in its consistent relationship with other pre-existing texts, the text is stylistically incorporated in with the view to reconstructing and revalorizing the African altered history and culture while portraying the reality of women's condition in male African hegemonic societies. It concludes that the realization of any literary text and preoccupation is relational to existing texts.
\end{abstract}

Keywords: Style and Stylistics; Textuality; Intertextuality; Dialogism.

"The good of a book lies in its being read. A book is made up of signs that speak of other signs, which in their turn speak of things. Without an eye to read them, a book contains signs that produce no concepts; therefore it is dumb."

- Umberto Eco, The Name of the Rose 


\section{Introduction}

Wellek and Warren (1968) quoted by S. A. Ogundokun (2013) affirm thus: "Literature is a social institution, using as its medium language, a social creation...Literature represents life and life is in large measure, a social reality, even though the natural world and the inner or subjective world of the individual have also been objects of literary imitation" (pp. 43-44). This implies that in literary creation, the presentation of one's thematic preoccupation, motifs, ideas, ideologies and philosophies is best achievable through the use of language which largely depends on individual maneuverings in relationship with the pre-existing communication codes.

In view of the above, T. S. Eliot (1958), in his renowned essay, "Tradition and the Individual Talent", postulates that; "No poet, no artist of any art, has his [sic] complete meaning alone: rather, what is important is the poet's relation to the dead poets and artists" (p. 15). And Roland Barthes $(1981,1974)$ shares the same opinion that "No text makes sense without other texts. Every text is a new tissue of past citations" (Roland B. 1981 in Andrew B. and Nicholas R., 2004, p. 6); hence it foregrounds that Adebowale's text at a point, consciously or unconsciously, interacts with some of the dead poets and artists which denote the pre-existing texts. Thus, a cursory look at stylistics and style suffices as the study intends to deconstruct how the author has related with pre-existing hypo-texts.

Bally and Riffatere, Widdowson and Ngara, Leech and Short, Friedman and Mclaughlin, Nils Enkvist among others are a few of very numerous scholars of style and stylistics that abound around the globe. Nina Nørgaard, Rocío Montoro and Beatrix Busse (2010) define stylistics as the study of the ways in which meaning is created through language in literature as well as in other types of text (p. 1). Then, in what seems to be a universal conception of stylistics among linguists and stylisticians is that stylistics simply defined as the (linguistic) study of style, rarely undertaken for its own sake and simply as an exercise in describing what use is made of language (Leech G. and Short M., 2007, p. 11, Ufot B., 2006, p. 13, Nozar Niazi, 2013, p. 118, Varghese L. M., 2012, p. 46). Thought presentation in literary creations can also be considered from the stylistics viewpoint as copiously annotated in Shahid Ahmad \& Shanthi Nadarajan (2020) and Samuel Alaba Akinwotu \& Fatai Saliu Ekunnusi (2020) adopt the discursive-stylistic approach to unravel leadership crisis vis-à-vis sociopolitical flux in some selected works of Wole Soyinka, and similarly Yeibo E. (2011) examined the mood structures in some selected poems of J. P. Clark-Bekederemo while using the approach of discourse-stylistic analysis in the study. But, however, for style, it is relational and multidimensional. While the psychologists see style as a form of behavior; to the rhetoricians, it is the speaker; the philosophers take it to be an implicit speaker, this foregrounds that every discipline has its interpretation of style.

Meanwhile, among the numerous conceptions of style summed up as "a writer's way with words, the artist himself', the study samples a few on which it centers. While Nina Nørgaard, Rocío Montoro and Beatrix Busse (2010) see style as the motivated choice from the set of language or register conventions or other social, political, cultural and contextual parameters; the inference of meaning from the choices made is then an equally difficult task because it has to move between a continuum of seeing each choice as stylistic and meaningful and potentially innovative, on the one hand, and of embracing complex conventions and norms, on the other (p. 156), and for Leech and Short (2007) who postulate that it will be safer to think that style is the linguistic characteristics of a particular text' (p. 11); and in relation to this study, Nils Enkvist (1978) affirms that style is comparison, a relation, a differential; whose total impression of a text may often arise from a complex network of such comparisons which are performed by matching a text against a whole set of experiences of others texts, similar and different that emanate from a spectrum of contexts, situations and backgrounds (p. 175). A pensive comprehension of Enkvist's view of style is a 
pointer to textual dialogism that characterizes the theory of intertextuality. But then textuality is instrumental to intertextuality.

Towards the end of the nineteenth century, there was a change in the notion of "literary work" to the concept of "literary text", where the emphasis is made on the textuality. However, this change does not negate the pluralism of the twentieth century as a century of theories. M.E.M Kolawole (2014) conceives this change as a pointer to the fact that contemporary literary theories require some attention in prevention of the elimination of the literariness in literary studies. Therefore she opines; "Textuality is a concept in linguistics and literary theory that refers to the attributes that distinguish the text (a technical term indicating any communicative content under analysis) as an object of study in those fields" (p. 192). In its totality, textuality is a means of preventing the elimination of the literariness of the literary studies, especially in the Third World and specifically in the postcoloniality.

The discourse of textuality also necessitated the concept of transtextuality; the textual transcendence of text. According to Gérard Genette (1992), "transtextuality is all that sets the text in relationship, whether obvious or concealed, with other texts" and it "covers all aspects of a particular text", maintaining that transtextuality is more encompassing than intertextuality (pp. 83-84). Genette further maintains that transtextuality has four components namely; intertextuality, paratextuality, architextuality, metatextuality and hypertextuality (also known as hypo-texts uality). Nevertheless, the limitation of this study is the deconstruction of the elements of intertextuality on which Bayo Adebowale relies in his incorporation Lonely Days (2006), with the view to maintaining the literariness of the text.

Bayo Adebowale born 6 June, 1944, a Nigerian poet, prolific writer, novelist, and critic, from Adeyipo, Ibadan, the capital Oyo State, the Western part of Nigeria; authored The Virgin (1985), that is adapted into two films one of which is The White Handkerchief (1998) among others, meticulously examines some of the violent punishments mete out to widows from the feminist perspective in his work Lonely Days (2006). The literary text presents widows of the world, especially in Africa, as targets of objectification, stigmatization, dewomanization, repression and hostility, forever leading a life of aloofness - silenced, subdued and humiliated - with their fundamental $h$ (wo)man rights trampled upon by the hegemonic custodians of traditions. With his dialogism with the existing texts, Adebowale has successfully graphically recorded and ingeniously woven the ordeals and tribulations of these widows into the archetype of Yaremi in Lonely Days.

Lonely Days has attracted several literary, sociological, psychological and linguistic criticisms since its publication. While Olugunle Wole (2018) and S. C. Moussa (2019) in their sociologically comparative criticisms of the text, examine the phenomenon of domestic violence against African women which foregrounds the shift in the discourse of feminism from liberal to radical, on the psychological ground, Olugunle Wole (2019) comparatively examines the influences of the psychic apparatuses of Yaremi and Emma Bovary on their behaviors in relation to their daily psychological exigencies. Linguistically, while Raïmi F. A. (2016) examines typology and significance of proverbs and proverbial devices in the text, F. M. Onipede (2019) considers how different meanings and ideologies are constructed, processed and legitimized in social practices that would enable Women liberation in African maledominated societies.

Importantly however, this study aims at contributing to the number of linguistic criticisms of this literary text, Lonely Days, while deconstructing the stylistic dialogism and incorporation of the text in the face of the elements of intertextuality, the objective of this study is to unearth and demonstrate how Adebowale, in his Lonely Days (2006), has related in either a compulsory, optional or accidental manner with existing ideas and ideologies, mours, legends and myths and preexisting communication codes. This is, however, preceded by a brief look at the theory of intertextuality and methodology to 
be followed by the textual deconstruction of the text under study, then some findings and recommendations in the conclusion.

\section{Methodology}

The term intertextuality, popularized especially by Julia Kristeva, is used to signify the multiple ways in which any one literary text is in fact made up of other texts, by means of its open or covert citations and allusions, its repetitions and transformations of the formal and substantive features of earlier texts, or simply its unavoidable participation in the common stock of linguistic and literary conventions and procedures that are "alwaysalready" in place and constitute the discourses into which we are born. In Kristeva's formulation, accordingly, any text is in fact an "intertext" - the site of an intersection of numberless other texts, and existing only through its relations to other texts (M. H. Abrams and Geoffrey G. H., 2009, p. 364).

In 1958, a group poststructuralist championed by Philippe Sorrels and JeanEdern Hallier in collaboration with Roland Barthes, Jacques Derrida, Jean-Pierre Faye, Umberto Eco and Gérard Genette created a literature review, Tel Quel. This brought a radical change to the traditional approach of literary interpretation that marked the starting point for Julia Kristeva's proposition of the theory of intertextuality; the synthesis of Saussurean semiotic and Mikhail Bakhtin's dialogism - an idea that "sees works of literature to in communication with each other and with other authors" (Dobie A. B., 2012, p. 38). Besides, it is expedient to note that Ferdinand de Saussure (1857-1913), Mikhail Bakhtin (1895-1975), and Roland Barthes (1915-1980), be taken as the forerunner of intertextuality. To this group of forerunners is the poet-critic T. S. Eliot (1888-1965) with regard to his insights that sound semiintertextual as presented in his "Tradition and the Individual Talent". Eliot defining the relation between a work and tradition and culture, which is a vast network of texts, and in which all other texts reside synchronically, paved the way for the quasi-intertextual assumptions that every author has and should have a historical consciousness and no text exists of its own in the tradition. This paper presents Eliot's ideas as contributory but limited endeavor in intertextuality. Intertextuality, in its broadest sense, is a poststructuralist, deconstructionist and postmodernist theory that changed the concept of text, recognizing it as an intertext owing to the interrelations between texts and texts' absorptions of other texts; that is to say the lien between the hypertext and hypo-texts.

However, standing on G. Allen (2000) and Mevlüde ZENGIN (2016)'s shoulders, intertextuality is a term that implies a literary theory that has became widely used. In practice, this phenomenon itself dates back to antiquity when the first recorded human history and the discourses about texts began to exist. However, the notions and practices of intertextuality in such a distant past as antiquity and the origins of intertextuality as a phenomenon especially in the Greek and Roman art and culture will be kept beyond the scope of this study; rather the current study will focus on intertextuality as a literary theory and practice in the deconstruction of a literary production through the markers of the theory as seen in the text under study.

Again, intertextuality is the distinction between work and text. A work, for the theorists of intertextuality, is a product which is consumed and a text is a process which is produced. Intertextuality is a theory which provides the reader with numberless ways of deciphering the texts including literary works because it considers a work of literature, as it views all texts, not as a closed network but as an open product containing the traces of other texts. In effect, it was Kristeva who first saw no discrimination between the literary and nonliterary texts. The primary focus in intertextuality is the interdependence of texts. All texts are intertexts because they refer to, recycle and draw from the pre-existing texts. Any work of art, for Kristeva, is an intertext which interacts with the other texts, rewrites, transforms or parodies them.

An intertext has also the power of subverting and reacting against other texts in 
the whole discursive field as in the case of the post-colonial discourses such as Achebe's Things Fall Apart (1958), Le Clézio's L'Africain (2004), among others. However, this is outside the limitation of this current study. But theorists engaging with intertextuality claim that the existing knowledge of the reader who is situated in a certain cultural and historical position is a determinant among many others in giving the meaning to the text; thus the reading process is an active endeavor (Mevlüde ZENGIN, 2016, p. 301). Within the limit of this study which shall be deconstructed in the "textual incorporation", according to Ayeleru L. B (2001), intertextuality suggests a range of links between a text and other texts emerging in diverse forms as direct quotation, citation, allusion, echo, reference, imitation, collage, parody, pastiche, literary conventions, structural parallelism and all kinds of sources either consciously exploited or unconsciously reflected. By so doing an intertext transforms or reproduces the texts preceding it as this will be fully discussed hereafter.

With the methodology of textual analysis, while considering the elements of intertextuality in the literary text, the deconstruction of the textual incorporation of Lonely Days will be fully brought to the foreground in the subsequent paragraphs of results and discussion.

\section{Results and Discussion}

As earlier noted, Adebowale's Lonely Days (hereafter refers to as $L D$ ) brings the deplorable conditions and inh(wo)man treatments of the African women especially the widows to the foreground. Since it will be presumptuous to claim to have the knowledge of the number of hypo-texts that influenced the hypertext, the textual deconstruction of the literary text before us will be done in the manner that shows the dialogism of the hypertext with the existing hypo-texts as they enable the creator to realize his thematic preoccupations through the elements of intertextuality.

It is de rigueur to commence the task from the para-textual viewpoint. Paratextuality simply shows the relationship between a text and the para-texts that inform the form and content of the text. These para-texts include the title and subtitles, the preface, introduction, dedication and etc. In view of this, the title of the text, Lonely Days, is a composition of a qualifying adjective, lonely, which means 'a situation of unhappiness because one has no friends or people to talk to; or a situation or period of time, sad and spent alone'. This adjective had been in existence long before the publication of the literary text in the year 2006. Besides, the second word, the plural noun, composing the title, days, which implies 'a period of twenty-four hours; the time between when it becomes light in the morning and when it becomes dark in the evening; the hours of the day when you are awake, working, etc'. Thus, in relation to Adebowale's thematic preoccupations, the intertext of the hypo-texts; lonely days, become a nominal group that explains the concept of loneliness that has been living with humanity since creation. It also greatly informs readers of the content of the hypertext and foregrounds the lonesomeness of the archetypal Yaremi's; the female-protagonist, in the face of dewomanization and series of illtreatment she receives from her in-laws following the demise of her cherished husband, Ajumobi;

These were lonely days indeed. Yaremi felt thoroughly abandoned, like a stone at the bottom of a lake.... And now, loneliness... Yaremi's days dragged lazily on, in a haze of solitude and lonesomeness..., dark lonely days and lonely nights.... (LD, pp. 34)

Adebowale uses this nominal group nearly in every page of the text to show the irritable conditions of the widows and to show that the widows' days are indeed helplessly lonely. Unarguably, Adebowale's inspiration was triggered by his relationship with the existing ideas and societal realities in the course of incorporating the text.

Moreover, at the very opening pages of the text, Adebowale indicates for whom he incorporates the text; Olukunle, Ayodeji and Akintade - The Three African Musketeers - 
who were probably hunters, with a poem written in form of an Ode ( $L D, \mathrm{p}$. iii). This unarguably informs readers the source of the creation of the archetypal Ajumobi, the brave hunter and dead husband of Yaremi. And in the meantime, Adebowale informs readers right from the dedication of the text his total support and commitment to the plight of women with the particularity of widows. This dedication is done in favor of 'the twenty-one valiant widows of the Village of Adeyipo whose days are lonely, who weep sore at night with none to comfort and whom all allies have betrayed' ( $L D$, p. v). In addition to the dedication, Adebowale also shows readers that he has one eye on the deplorable, irritable and despicable conditions African widows are subjected to despite the great loss they suffer from the death of their husbands. Adebowale tags this page Entrance Verse which tells a lot about the entirety of the dulce and utile of the text. This Entrance Verse subtitled; The Widows, is a heart-piercing twenty-five line poem of unequal meter with melancholic tone that copiously summarizes the central motif of the text ( $L D$, pp. vii-iii). With his dialogism with the pre-existing socio-cultural facts and incidents, Adebowale has successfully sculptured the female-protagonist, Yaremi, an archetype of widows that are peripatetic in African hegemonic societies with a view to foregrounding their pitiable conditions. No doubt, this is instrumental to the development of his central motif.

Furthermore, among other elements of intertextuality that facilitate Adebowale's incorporation of his text is borrowing. With the understanding that every postcolonial writer is a translator; a view that corroborates the opinion of Emmanuel Obiechina (1990) who identifies the task of translation required of the (West) African writers being a diglossic continent, he remarks that these writers, in the course of their literary creation, translate from a mother's tongue to another colonial language. In the same vein, Soyinka and Achebe are not left out in the discourse of the task required of literary creators in the face of colonial language(s) use. While Achebe, with a skeptic undertone, feels that the colonial language(s), English language, would be able to bear the weight of his African experiences but it could not; what justifies his frequent use of Igbo idiolects in his literary creations to foreignize them, Soyinka on the other hand pontificates on the ability of the colonial language(s), English language, to bear the weight of the 'African experiences through the domestication of the English language in what can be called African English'. He maintains that when such alien language is borrowed with the view to sculpting or painting in it, it 'must begin by co-opting the entire properties of that language in our matrix of thought and expression. We must stress... stretch it, impact and compact it, fragment and reassemble it'; what justifies his domestication of the colonial language in his literary creations (V. S. Dugga, 2007, p. 166). Soyinka's view does not seem to appeal to Adebowale but rather Achebe's; thus, it is valid to posit that Adebowale's style of borrowing is influenced by Achebe.

But then, J.-P. Vinay et J. Darbelnet (1958) affirm that borrowing is one of the procedures of translation. In translation, borrowing is employed for the purpose of combing metalinguistic lacunae as Adebowale voluntarily recourses to it for stylistic purpose while evoking the local color of africanity and cresting his signature on the text. The abundance of borrowing in this text, $L D$, enhances its stylistic foreignization.

In view of the above, the Yoruba cultural influences in well perceived in Adebowale's style of incorporating the text with his several borrowings of the autochthonous idiolects; whether at the syntactic or the lexical level, not only for stylistic effect but also to engrave his signature of local coloring as peripatetically seen in the text. At the syntactic level, an example of such borrowings is used by the female-protagonist, Yaremi, while she recants her eventful childhood to her grandson, Woye, as they would make jibes of dwarfs while tiptoeing and singing the mockery song; Ta ló ga jù lábà! ( $L D$, p. 35), translates as, "Who is the tallest in the village!" (I did all the translations in this study but otherwise stated). And at the lexical level, veritably there are metalinguistic lacunae which Adebowale stylistically left uncombed even as advised by Soyinka. In his 
stylistic description of some eco-critical and mythological elements such as animals, trees and myths, he retains the local names of these elements. This retention also enables him exhibit the traditions, culture, mœurs, norms and belief of the people of Kufi village vis-à-vis certain birds and phenomena in Africa as these birds from the forest of Aku are seen as witches. He borrows the local names of birds such as; egà (a brownish bird), ò̀rì (a white bird with a long beak), aasè (a bird with a greenish beak), gúnnugún (vulture), èlúùlú, (a bird believed to be capable of causing rain in the African milieu), ( $L D$, pp. 42,120$)$. He retains the local name of other objects such as charm; jùjú, the freshness of palm-wine; àhá, some trees; akoko, idígbó, arere, some mythological elements; jókòjéé, ìparadà, monígèdègédé, ògaǹwò, kètèmbè, sákárà, konkoso, gbèdu, just to mention a few ( $L D, \mathrm{pp}$. 41-61). The use of borrowing in the text establishes the stylistic incorporation of the text within the kaleidoscope of intertextuality to foreground its foreignization.

In addition, allusion and references, are other markers of a text's dialogism with the pre-existing texts, intertextuality. While allusion is an indirect stylistic method of referencing an object, a person or an event, reference is the very act, the direct method of mentioning the author of a quotation and the text where such quotation is drawn; a precise indication that enables the identification of an object. In the course of his textual incorporation of the text, $L D$, he employs an implied reference, an allusion, to the Bible when Yaremi's husband, Ajumobi describes the physiological portrait of the new wife he looks forward to marrying as a derision and check of his wife's excessiveness. He alludes to the third verse of Psalms One when he threatens Yaremi; ... and she ripens with new fruits like banana tree on a river bank! ( $L D, \mathrm{p}$. 58). Still on Biblical allusion, Adebowale recalls the conseils of the chapter from the first verse through eight of Ecclesiastes that bother on the fact that everything has time to show Yaremi's swiftness to her domestic chores following her lonesomeness after the death of her husband saying; There really should be time for everything. Time to be idle. Time to get down to serious work... A time to arrive and a time to depart... (LD, pp. 30-31). Again, it should be noted that Adebowale also makes use of a classical allusion - a reference to an event - to cushion the psychological pain Yaremi suffers due to few occasions where Ajumobi has "turned her to a punching-bag" according to Olugunle Wole (2018, p. 134). In this classical allusion, Yaremi believes that she will have the maltreatments she has been suffering from her husband back on him in the women's world. She says; Men could be slapped by the women, and be kicked 'inside the net or over the bar', like rubber balls ( $L D$, p. 64).

Again, another marker of Adebowale's intertextuality in the incorporation of the text is pastiche. Pastiche is the imitation of the style of a literary creator, a pre-existing literary sculptor, with a view to using such style in the hypo-texts. The hypo-text writer imitates the style with which a place, characters, events, among others is done in hypertexts. Adebowale's style is a pastiche of Chinua Achebe as this has been discussed above under borrowing as a marker of intertextuality. But then, a critical consideration of the physiological and psychological attributes of Achebe's Okonkwo in Things Fall Apart (1958), are almost the same with Adebowale's Ajumobi in $L D$. Achebe physiologically sculpts Okonkwo to be muscular; Every nerve and every muscle stood out on their arms, on their backs and their thighs..., and his psychological attribute summed up; ... And he did pounce on people quite often. He had a slight stammer and whenever he was angry and could not get his words out quickly enough, he used his fist.... Okonkwo ruled his household with a heavy hand. His wives, especially the youngest, lived in perpetual fear of his fiery temper and so did his little children (Achebe C 1958, pp. 3, 11). Similarly, almost with the same structural parallelism, Adebowale paints Ajumobi physiologically and psychologically thus; The muscles of Ajumobi's strong arm were massive.... Ajumobi had always been in absolute control of his household (LD, pp. 52, 54), and as a stutterer like Okonkwo thus; You must-must be mad, Yaremi!... What an-an insult! I've ne-nenever been so much insu- insulted in my whole life. Just let me cat- cat- catch you... and show you the mama-man in me. Ya-Yaremi... I'll beat you silly. I'll th-thra- thrash you, li- li- like the 
whea- wheat in- in a barn. I'll sei- sei- seize the pestle inside the mortar and poun- pounpound you hard with it, likeho- ho- hot yam (LD, pp. 62-64).

Still on the pastiche of character, Adebowale relates with Achebe's character of Nwoye to create his own character of Woye. These two characters are created on a common ground from different cultures; Igbo and Yoruba respectively. And again, a close consideration of their nominalization; apart from the difference in de-clustered consonant ' $\mathrm{N}$ ' in the names Nwoye and Woye, the syllable, the rhythm and manner of articulation is almost the same. Unarguably, with the establishment of pastiche in $L D$, Adebowale has incorporated the text, thanks to his dialogism with the pre-existing literary creators.

The acquisition of written competence is preceded by the oral. This implies that in Literature, the oral aspect is as important as the written as against the Eurocentric cultures that hold this fact in derision or oblivion. This makes Martha van der Drift (2014) postulate that 'for Eurocentric cultures, the importance of oral tales is often overlooked or even forgotten' (p. 88). Hence, it can be inferred that the plot of the hegemonic European cultures is not unconnected with their inordinate penchants for universal cultural imperialism and the subjugation of every non-European culture achievable through the derision and imposition of the European cultures' carrier and preserver to be foisted on the nonEuropean cultures through the obliteration of orality in its totality. In view of this, postcolonial writers; most especially the African writers, conscientize themselves of the fact that orality in written literature can never be obliterated, and that the African Oral Literature preceded the Written and therefore inject in a métissée style African myths, folktales, legends and the entirety of orality in the ideal silo for the preservation of the societal realities in documentation for the purpose of revealing the societal virtues and vices with a view to conserving and effecting the needed amendment for the sake of posterity, African Written Literature.
Aschroft et al (2007) affirm that the dominance of anthropological texts in the recording of 'oral' forms was part of this process of undervaluing, helping to convey the impression that the oral was not as socially or aesthetically valuable as the literary. In classic anthropology, orality was often designated as 'traditional' in a discourse that opposed it to the 'modern', and it was assumed to be both of the past and immutable (p. 152). Thus, the phenomenon of orality might be degradable in the European Written Literatures but not in the African Written and other Black Literatures. Since African writers place much value on orality in Written Literature, Balogun L. I (2011) conceives Oral Literature as;

L'usage esthétique du langage non écrit, l'ensemble des connaissances et activités qui s'y rapportent; lorsque la parole, le langage et le discours sont non écrits et fondés sur des caractères oraux. L'oralité caractérise une situation sociale dans laquelle la communication orale est privilégiée (pp. 2-3).

The aesthetic use of unwritten language, the related assemblage of knowledge and activities; when words, tongues and speeches are unwritten established on characteristics of orality. Orality characterizes a social situation from which communication profits (My translation).

Furthermore, Jacques Chevrier (1986) in Igbonagwam C. (2020) opines that; "l'oralité est une mode d'expression qui consiste à décrire par des métaphores, des contes, des mythes, des légendes etc, possède aussi, sa méthodologie qui est différente de celle de l'écriture» (p. 66), which translates as « orality is the mode of expression that consists the metaphorical explanation of folktales, myths, legends, etc with different methodology from the written » (My translation).

Consequently, in the textual incorporation process, Adebowale conscientizes himself, he relates with preexisting folktales and fables, myths and legends, proverbs, incantations and songs; 
markers of intertextuality, that is abundant in the Yoruba oral tradition and cosmology, and transliterates them in his textual incorporation, unarguably for the purpose of preservation.

As regards folktales and fables as markers of textual dialogism, while folktales are stories usually handed down orally from generation to generation; often explaining something happens in nature or convey a certain truth about life, fables on the other hands fables are succinct fictional stories, in prose or verse usually recanted in the moonlight usually after diner, that feature animals, mythical creatures, plants, inanimate objects or forces of nature anthropomorphized; and that illustrate or lead to an interpretation of a moral lesson which may be added explicitly in a pithy maxim eventually. Remarkably, Adebowale relates a great deal with folktales and fables in his textual incorporation of the text. An instance among the numerous is seen when Yaremi; a dexterous storyteller, tells Woye, her grandson, series of fables and folktales which she knows delight him;

In the animal world, the blind earthworm digs a vertical trench to hide from his enemies; the female chameleon changes her festival garments, every second, to win the heart of her suitor... (LD, pp. 83-84)

These fables and folktales prove psychotherapeutic as Yaremi successfully takes care and brings Woye out of his sick bed.

In the meantime, myths and legends as genres of oral literature are other markers of intertextuality present in the process of textual incorporation of the text. Myths and legends tell a story or an event that had taken place in the primordial time, the ancient time of creation. Stories that were told to explain natural events, describing the early history of a people; sacred stories about gods, deities and supernatural beings whose lives have influenced others under symbolic forces of nature and the aspect of human's condition. In $L D$, following Yaremi's ill-treatment by her husband, Ajumobi, Adebowale recourses to myths and legends for another psychotherapeutic essence of psychological compensation by Yaremi to expose his character's thought where; in the spiritual world where men are powerless, she hopes to avenge her husband. According to the myth and legend;

... in the spirit world where, as they said, women could give back onto men what they received from men on earth.... Men's right to bully is withdrawn, in the spirit, and given to women... (LD, pp. 63-64).

Still on orality, there is proverb, another pointer to intertextuality in the text. Proverb is a well-known phrase or sentence that is full of wisdom with condensed words and gives advice or says something that is general true through which the mastery of a language is demonstrated through the use of proverb. The use of proverbs expresses wisdom and mastery of a language in a traditional context. This corroborates Achebe's position in his Things Fall Apart (1958) that proverbs are the palm-oil with which words are eaten (p. 6). Thus, $L D$ relates with some proverbs in the course of its textual incorporation. Adebowale makes use of these proverbs to show his skills and mastery of the indigenous language and culture he reconstructs. In of of the instances where Adebowale employs proverb while incorporating the text under study is seen when Yaremi, the female-protagonist, returning from the stream, meets with some young ladies whom she deems lazy; she advises that against such laziness as their future husbands would not take that from them especially when they are famished. She says; A hungry man is an angry man. Your man will roar a lion, and growl like a tiger; his bellow will consume you! (LD, p. 18).

Incantation is another element of orality that marks the dialogism of the text with the pre-existing ones. Incantation is a composition of specially condensed and magical words uttered with a view to evoking a spirit or whatever power. In most authentic African milieux, incantations are said with the aim of evoking a metaphysical power or spirit to help, defend, protect or rescue the chanter when in danger or for a particular purpose. In his cultural reconstruction, Adebowale brings to the foreground the important roles that 
incantations play in the Yoruba culture and the daily lives of those who practice traditionalism.

The text, $L D$, has several instances of relating with incantation. In an instance, Ajumobi, Yaremi's husband, boasts of himself as a brave hunter to his wife, that he can make himself invisible before his enemies; that he can transmogrify himself that no one will see him, transforms himself a chameleon and remain undetectable among the green leaves as he chants an incantation of such capability;

Nobody knows the secret of the hoe. Nobody knows what the cutlass conceives. No one can unravel the mystery of monigedegede. It will perch today, it will perch tomorrow. Finally the butterfly escapes from its enemies with its mesmerising moves - that's me, Yaremi! (LD, p. 51)

In addition, there is a use of incantation for the purpose of praying for Yaremi's victory over her adversaries;

Yaremi was sure she would triumph in the end over the forces of evil. Because 'ojuoro floats tente on the surface of the river', she would float tente above enemies. Because 'osibata floats tente on top of the forest lake', she would float tente above detractors... (LD, p. 118)

Song is another element of orality that also indicates textual relationship with other texts in Adebowale's textual incorporation of $L D$. Recalling that a song is an imaginary story (sometimes full of emotions and sentiments) composed purposely to be sung, known as Chorus in the generic drama, comments on the actions, characters and events in the past present or future in the intrigue of the literary work. However, in the African culture, songs are sung for differences purposes as they teach moral lessons, source of encouragement and invigoration for those working to cushion the fatigue of the work and to head them on as in the case of Yaremi. They are related to sociocultural manifestations and human activities as well.
In the process of incorporating the text, Adebowale employs a great deal of songs for the purpose of post-colonial coloration, showing the elevated position occupied by song in the daily lives of Africans regardless of gender and status, and engrave his cultural signature's in the text. Nevertheless, citing two examples of these numerous examples; one can be seen after the death of Radeke's husband, one of the widows of Kufi village, she kneels before the carcass of her husband while she sings the traditional songs of widows to prove her innocence and non-involvement in her husband's death and lamentations:

If heaven was like going to the market in the morning, And returning home in the evening I would have followed my husband And run errands for him... Urged him on and on - To let him know that it would never be Out of sight, out of mind... (LD, p. 28)

Again, following Ajumobi's death and the swift change in Yaremi's status, with a view to repressing and subliming her psychological exigencies, and to encourage herself against loneliness, laziness and boredom, she becomes workaholic. Remarkably, at every time she works, she ensures that she must sing diverse of songs soothing the contexts she finds herself. Occasionally she sings widows' songs but most times she sings to invigorate and encourage herself while she gets busy. An instance is where she sings the number-game song with Woye, her grandson, in order to invigorate, encourage and guide him against laziness. At the middle of the singing, she tells Woye the importance of songs to them, the adults when she says; Work was music to us, Woye. We would spread out taffeta with laughing eyes and allow the joy of work to radiate on our countenance, all along singing merrily (LD, pp. 7-10).

\section{Conclusion}

In the guise of conclusion, the linguistic Kristevan methodology of intertextuality has enhanced the deconstruction of Adebowale's style of incorporating the textual elements of Lonely Days (2006) which establish the fact 
that his text has greatly benefited from its dialogism with the pre-existing ones. This reveals the richness of African pre-existing texts such as proverbs, songs, incantations, etc as against the colonial writers who claimed that Africa had no culture whatsoever.

Thus, it is discovered that all is said but what is obtainable is the reworking and reconstruction of the said in a renewed style. Therefore, no literary gods can the precursor of a concept, theory or approach without relating with the existing ideologies, ideas and phenomena. This is in tandem with the position of Ashcroft et al (2002) that each new text, whether novel or commentary, both builds upon its predecessor and by a series of 'paradoxical juxtapositions' deconstructs the earlier work by recasting and re-distributing its elements (p. 152). This implies that the text understudied has; by a stylistic compulsion, option or accident, dialogued, interrelated and benefited in no small measure from the preexisting texts. This means that the realization of the text as well as the communication of its thematic preoccupations are possible through its dialogism with the pre-existing ideas, ideologies, mœurs, legends, myths, incantations, songs, proverbs, citations as well as the pre-existing communicative codes.

Thanks to all these, Bayo Adebowale successfully gives voice to women most especially African widows in their pitiable, deplorable and inh(wu)man conditions in the face of the ill-treatments they receive from the modern hegemonic African society as against how Olugunle Wole (2018) opines a careful study of African culture reveals that man should treat women with dignity and respect instead of abusing them, they are to be cherished and not brutalized (p. 138).

Undoubtedly, from the view point of intertextuality, this text is well incorporated as it has meticulously dialogued with the preexisting texts. But then, it will be necessary to consider how the use of language from the viewpoint of syntax and semantic has facilitated the realization of this writer's thematic preoccupations.

\section{References}

Abrams, M.H. and Geoffrey, G.H. (2009). A Glossary of Literary Terms Ninth Ed. Massachusetts: Wadsworth Cengage Learning.

Achebe, C. (2008). Things Fall Apart. London: Pearson Education Limited.

Adebowale, B. (2006). Lonely Days. Ibadan: Spectrum.

Andrew, B. \& Nicholas, R. (2004). Introduction to Literature, Criticism and Theory Third $E d$. London: Pearson Education Limited.

Allen, G. (2000). Intertextuality. London: Routledge.

Ashcroft, B. et la. (2002). The Empire Writes Back: Theory and practice in post-colonial literatures, London: Routledge.

(2007). Post-Colonial Studies: The Key Concepts Second edition, London: Routledge.

Ayeleru, L.B. (2001). Sony Labou Tansi's Literary Idiolect in La Vie et Demie and L'État Honteux. A Ph.D Thesis, University of Ibadan, Nigeria.

Balogun, L.I. (2011). Initiation à la Littérature Africaine d'expression française. Lagos: Aifa Printing Production.

Barthes, R. (1974). S/Z. (Trans. Richard Miller, Preface. Richard Howard). New York: Blackwell.

Dobie, A. B. (2012). Theory into Practice An Introduction to Literary Criticism Third Edition. Massachusetts: Wadsworth Cengage Learning.

Dugga, V. S. (2007). "Holding Talks in England: Cross-Cultural Interface in producing Ola Rotimi" in Bakare Ojo Rasaki (ed) Ola Rotimi's Drama \& Theatre: Issues and Perspectives, Abuja: Root Books \& Journals Nigeria Limited. 
Eliot, T. S. (1951). "Tradition and the Individual Talent" Selected Essays, London: Faber.

Enkvist, N. (1978). "Stylistics and Text Linguistics" in Wolfgang Dressler (ed) Current Trends in Text Linguistics, Berlin: Walter de Gonyter.

Genette, G. (1992). The Architext: An Introduction, Berkeley: University of Carlifonia Press.

Igbonagwam, C. C. (2020). "Analyse des éléments de l'Oralité dans Quand On Refuse, On Dit Non d'Ahmadou Kourouma », Journal of Languages, Linguistics and Literary Studies, 9(5), 6670.

Kolawole, M.E.M. (2014). "From Metatexts to Intertexts:(Sub)Version of Women's History in Things Fall Apart, The Last of the Strong Ones and Purple". Perspectives on African Studies: A Multidisciplinary Approach, (Ed., Mary E. Modupe Kolawole pp. 188-209), Ibadan: Ibadan University Press.

Leech, G. and Short, M. (2007). Style in Fiction: A Linguistic Introduction to English Fictional Prose. Second Ed. London: Pearson Education Limited.

Moussa, S. C. (2020). "A Comparative Study of Widows' Plight in Binwell Sinyangwe's A Cowrie of Hope and Bayo Adebowale's Lonely Days", Advances in Social Sciences Research Journal, 7(4), 272-291.

Nørgaard, N. et al. (2010). Key Terms in Stylistics, London and New York: Continuum International Publishing Group.

Nozar Niazi. (2013). "A Stylistic Analysis of D.H. Lawrence's Sons and Lovers", IJALEL, 4(2), 118-126.

Obiechina, N. E. (1990). Language and Theme: Essays on African Literature, Washington D.C.: Howard University Press.
Ogundokun, S. A. (2013). "Satire as typified in Ramonu Sanusi's Le Bistouri des Larmes", Global Journal of Arts Humanities and Social Sciences, 1(2), 4350.

Onipede, F. M. (2019). "Women liberation in male-dominated society: A critical discourse analysis of Bayo Adebowale's Lonely Days", International Journal of English Research, 5(1), 110-115.

Raïmi F. A. (2016) “Typology and Significance of Proverbs and Proverbial Devices in Bayo Adebowale's Lonely Days", Research Journal of English Language and Literature, 3(4), 715-725.

Samuel Alaba Akinwotu \& Fatai Saliu Ekunnusi. (2020). "Leadership Debacle and Socio-Political Flux in Post Colonial Africa: A Discourse-Stylistic Analysis of Wole Soyinka's A Play of Giants and King Baabu", Journal of Language and Literature, 20(1), 92-102.

Shahid Ahmad \& Shanthi Nadarajan. (2020). "Thought Presentation in Alice Sebold's The Lovely Bones", Journal of Language and Literature, 20(1), 70-79.

van der Drift, Martha. (2014). Leclézien Hybridity: Relations Across Genres, Histories and Cultures in Selected Works. Une Thèse Doctorale remise à la Faculté de l'Université de North Carolina à Chapel Hill, Département des Langues Romances and Littératures (Français)

Vinay, J.-P. and J. Darbelnet. (1958). Stylistique Comparée du Français et de l'Anglais, Méthode de Traduction, Paris : Les Éditions Didier.

Ufot, B. (2006). An Introduction to Practical Stylistics. Nigeria: Solar Flares Communications.

Varghese, L. M. (2012). "Stylistic Analysis of Emily Brontë's Wuthering Heights", Journal of Humanities and Social Science, 2(5), 46-50. 
Wole, O. (2018). "A Comparative Reading of Domestic Violence against African Women in Chinua Achebe's Things Fall Apart and Bayo Adebowale's Lonely Days", AFRREV, 12(4), 128-139. DOI: http://dx.doi.org/10.4314/afrrev.v12i4. $\underline{13}$

. (2019). "The Interplay of Literature and Psychology in Literary Productions: Lonely Days and Madame Bovary", Journal of Comparative Literature: East \& West, 3(2), 163175. DOI: $\underline{10.1080 / 25723618.2019 .1710}$ $\underline{940}$

Yeibo, E. (2011). “A Discourse-stylistic Analysis of Mood Structures in Selected Poems of J.P. Clark-bekederemo", International Journal of Humanities and Social Science, 1, 16.

Zengin, M. (2016). "Introduction to Intertextuality as a Literary Theory: Definitions, Axioms and the Originators", Pamukkale Üniversitesi Sosyal Bilimler Enstitüsü Dergisi Sayi 25/1, Sayfa 299326. Retrieved from https://goo.gl/2YvLUF on 10th July, 2017. 